\title{
Mineralogical and Geochemical Properties of Greek Evaporites, Associated with Their Prospects of Industrial Use ${ }^{\dagger}$
}

\author{
Ioanna Badouna ${ }^{1, *}$, Spiros Neokosmidis ${ }^{2}$, Michael Stamatakis ${ }^{3}$, Christos Karkalis ${ }^{1,3}$, Nikolaos Koukouzas ${ }^{1}$ and \\ Petros Koutsovitis 4 (D)
}

1 Centre for Research and Technology, Hellas (CERTH), 52 Egialias, GR-15125 Marousi, Greece; karkalis@certh.gr or chriskark@geol.uoa.gr (C.K.); koukouzas@certh.gr (N.K.)

2 Hellenic Public Properties Company (HPPC) S.A., 7, Voulis Street, GR-10562 Athens, Greece; s.neokosmidis@gmail.com

3 Faculty of Geology and Geoenvironment, National and Kapodistrian University of Athens, Panepistimioupoli Zografou, GR-15784 Athens, Greece; stamatakis@geol.uoa.gr

4 Section of Earth Materials, Department of Geology, University of Patras, GR-26500 Patras, Greece; pkoutsovitis@upatras.gr

* Correspondence: badouna@certh.gr; Tel.: +30-6972557912

+ Presented at International Conference on Raw Materials and Circular Economy, Athens, Greece, 5-9 September 2021.

check for updates

Citation: Badouna, I.; Neokosmidis, S.; Stamatakis, M.; Karkalis, C.; Koukouzas, N.; Koutsovitis, P. Mineralogical and Geochemical Properties of Greek Evaporites, Associated with Their Prospects of Industrial Use. Mater. Proc. 2021, 5, 3. https://doi.org/10.3390/materproc 2021005003

Academic Editors: Anthimos Xenidis, Evangelos Tzamos and

Konstantinos Simeonidis

Published: 22 October 202

Publisher's Note: MDPI stays neutral with regard to jurisdictional claims in published maps and institutional affiliations.

Copyright: (c) 2021 by the authors. Licensee MDPI, Basel, Switzerland. This article is an open access article distributed under the terms and conditions of the Creative Commons Attribution (CC BY) license (https:/ / creativecommons.org/licenses/by/ $4.0 /)$.

\begin{abstract}
Greece is considered as one of the most common producers of gypsum-anhydrite in Europe. The low content of impurities of these evaporite minerals, their big reserves and the low cost of logistics costs makes them exploitable and applicable for a range of industrial uses. The current study endeavors to present the petrographic, mineralogical, geochemical and qualitative features of evaporite samples from seven selected localities of western Greece (Zakynthos Island, FiliatesThesprotia, Etoloakarnania and Kyllini region) and Crete Island. The studied evaporitic rocks are classified as a mixture of gypsum and anhydrite, where gypsum predominates. Other minerals present in minor amounts include celestite \pm calcite \pm dolomite \pm magnesite \pm sanidine and quartz Celestite $\left(\mathrm{SrSO}_{4}\right)$ was detected in all studied samples. The highest celestite value $(13.5 \%)$ corresponds to the region of Filiates, indicating that this deposit is prosperous for further research and potential Sr exploitation. Significant focus is also given on the assessment of the evaporite whiteness with respect to their mineralogical and geochemical composition. The aforementioned data aim to serve the dynamic Greek calcium sulphate industry by enhancing the evaporites' prospects of industrial use, providing potential applications for those not already exploited.
\end{abstract}

Keywords: evaporites; gypsum; celestite; mineralogy; geochemistry

\section{Introduction}

Evaporites are important industrial minerals with high financial value. Gypsum deposits are exploited for a plethora of industrial applications. Most of the extracted raw gypsum is used in the cement industry, as well as in wallboards construction. It is also used for decoration purposes, in agriculture as soil remediation, as, medicinal agents in the pharmaceutical industry and in chemical industry and metallurgy. The world gypsum production reached 150 Mtones during 2020, whereas USA (22 Mtones) and Spain (7 Mtones) are the biggest gypsum producers in world and Europe respectively. In Greece, the gypsum production was $\sim 0.7$ Mtones during 2020, corresponding mainly to the Triassic deposits of Etoliko and Katouna (Etoloakarnania region; Central Greece), and Altsi deposit in Crete Island (Southern Greece) [1].

Celestite $\left(\mathrm{SrSO}_{4}\right)$ is commonly found as cement material in brecciated marine evaporites [2]. Active celestite mines are located in China, Iran, Mexico, and Spain, accounting for almost 98\% of world's celestite production in 2017 [3]. In Spain, the Montevives and 
Escuzar deposits in Granada are the mainly exploited deposits. Other celestite deposits are located at the southeastern edge of the Troodos ophiolite complex in Maroni, (Cyprus), at the Arabian Gulf (Qatar), in the Neuquen basin (Argentina) and in Northern Tunisia [2]. Strontium has been included in the list of critical raw materials since 2020. Spain is the main global Sr-supplier and the only supplier in Europe, with a share of 31\% [4]. In this context, celestite is considered the main source of strontium-chemicals, which are used in the ceramics, glass, metallurgy and pyrotechnics industries [3].

The analysed evaporites of the current study are of marine origin and Triassic age, belonging to the Ionian Zone, part of External Hellenides, which were derived from the collision of Laurasia with the eastern continental margin of Godwana and are linked with the closure of one or more ocean basins [5]. The External Hellenides are composed by the Ionian zone along with the Zones of Pre-Apulian, Gavrovo and Pindos [6]. The Ionian Zone consists of the following three successive stratigraphic sequences [7]: (a) The pre-rift sequence, which includes the Triassic evaporites at the lower parts, followed by Middle Triassic to Lower Jurassic limestones, (b) the syn-rift Lower to Upper Jurassic sequence, which comprises limestones that locally turn to Ammonitico Rosso-types and (c) the postrift sequence that includes the Lower Cretaceous Vigla-limestones, followed by Senonian limestones and Paleocene-Eocene limestones. The sequence is covered by the sedimentary formations of the Oligocene flysch [8,9].

The present study focuses on investigating and highlighting the mineralogical, petrographical, geochemical and qualitative features of Triassic evaporitic rocks of western Greece and Crete Island (Southern Greece), taking into consideration their potential for future exploitation.

\section{Study Suite and Analytical Methods}

Our study rock suite consists of 25 evaporitic samples collected in the early 1920s that comprise 21 gypsum-rich, 2 anhydrite-rich evaporites and 2 calcite-rich evaporites. In particular, 5 representative samples were selected from gypsum active quarry of Biogyps Karvelis S.A. in Skopos Zakynthos, 3 samples from inactive gypsum quarry in Kastro Kyllini, 4 samples from old gypsum-anhydrite quarry faces in Katouna, 4 samples from active gypsum quarry of Biogyps Karvelis S.A. in Etoliko, 3 samples from gypsum deposits in Filiates-Thesprotia (not exploited), 3 samples from active gypsum quarry of Interbeton Construction Materials S.A. in Altsi East Crete and 3 samples from old gypsum quarry faces in Stomio West Crete (Figure 1). These samples were examined with respect to their petrographic, mineralogical, geochemical and qualitative properties. The aforementioned areas have been also studied in the past, sampled and analysed for their boron and chlorine content. The results did not show any specific enrichment of these element in the gypsum-evaporite samples [10]. Petrographic observations were conducted on polished thin sections using a Leica DM LM microscope with a digital photo camera CANON A95 adjusted to the microscope. Mineral chemistry analyses were conducted using a SEMEDS, JEOL JSM-5600 scanning electron microscope, XRD analyses were performed using a Siemens D5005 X-ray diffractometer and their interpretation with the DIFFRAC plus EVA software v.11 (Bruker-AXS, Madison, WI, USA) at the laboratory of the Department of Economic Geology and Geochemistry of National and Kapodistrian University of Athens (Greece). Whole rock chemical analyses for trace elements were carried out using an $\mathrm{X}$-ray fluorescence (XRF) and investigation on whiteness using a phasmatometer at the laboratories of the TITAN S.A. 


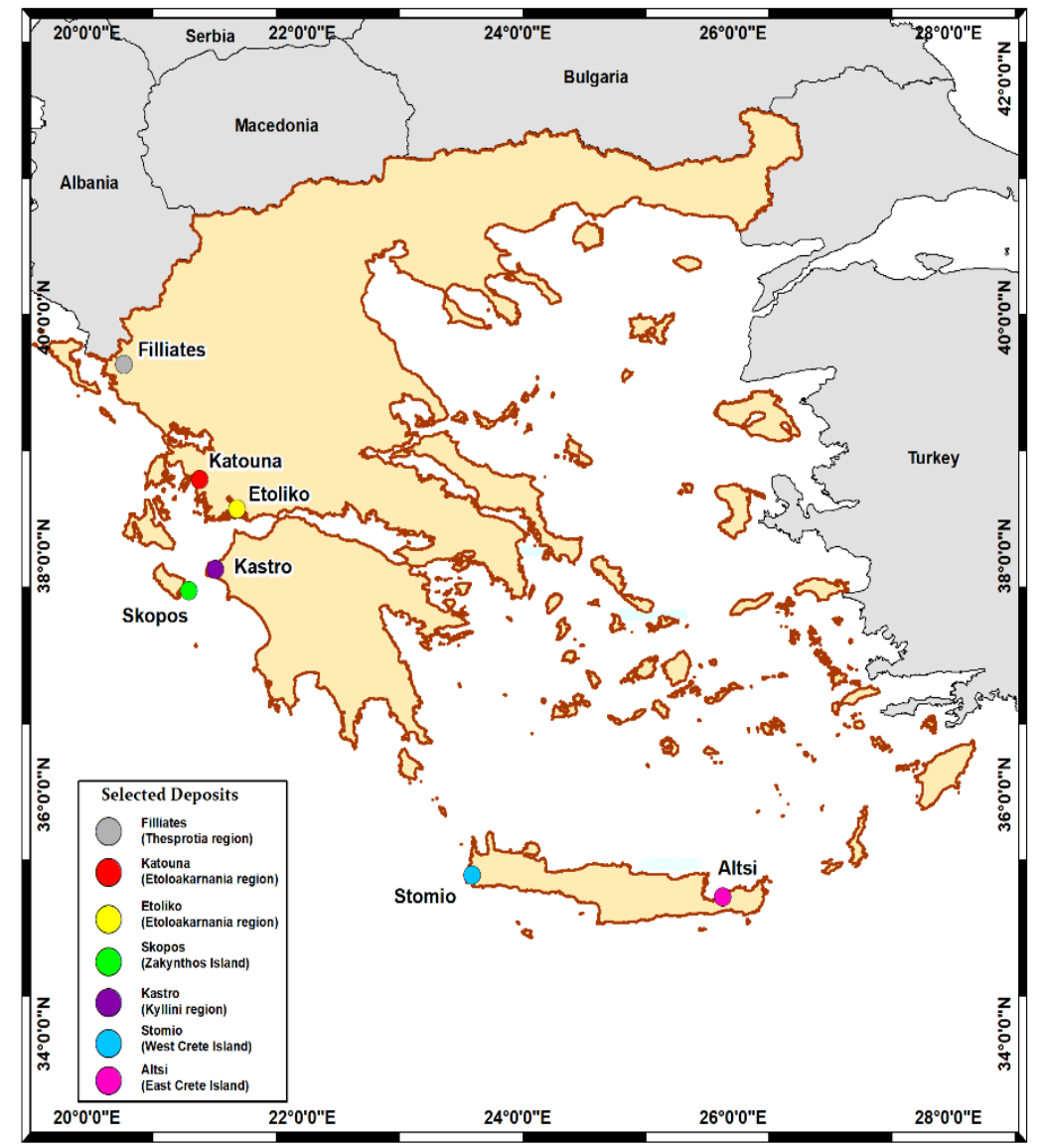

Figure 1. Map of Greece indicating the sample localities.

\section{Results}

\subsection{Petrography—Mineralogy}

Evaporitic rocks from our study can be distinguished into gypsum-rich, anhydrite-rich and calcite-rich evaporites. Their mineralogical composition was determined by detailed petrographic examination, coupled with XRD and SEM analyses.

\subsubsection{Gypsum-Rich Evaporites}

Gypsum-rich evaporites are predominantly composed by gypsum (ca. 80-100\%) and anhydrite (ca. 5-10\%), whereas accessory minerals include celestite \pm calcite \pm dolomite. Their texture is mainly alabastrine, usually transposing to granoblastic and heteroblastic. The first is characterized by the development of interlocking gypsum and anhydrite crystals with shadow boundaries, as well as by the polarization extinction of microcrystalline gypsum aggregates (Figure 2a). In the second case (granoblastic or heteroblastic), gypsum crystals of $0.02-1.5 \mathrm{~mm}$ size are randomly dispersed within the amorphous groundmass, forming distinct clusters and/or zones. In many cases, syn-sedimentary fluidal textures consisting of fine to medium grained gypsum are also observed (Figure 2b); these are more profound in gypsum-rich evaporites from the Altsi, Skopos and Kastro regions. Gypsum commonly appears as part of the fine-medium grained evaporitic groundmass or in the form of porphyroblasts, often hosting anhydrite inclusions. In some cases, gypsum has been developed as fracture-filling mineral within cavities or veins (Skopos, Etoliko and Katouna regions). Anhydrite appears as relict mineral phase or in the form of newly formed (secondary) crystals within veins. In the first case anhydrite is partly replaced by gypsum or hosted within the aforementioned gypsum porphyroblasts. Secondary anhydrite has been developed within veinlets that crosscut the gypsum-rich groundmass (ST-2). 

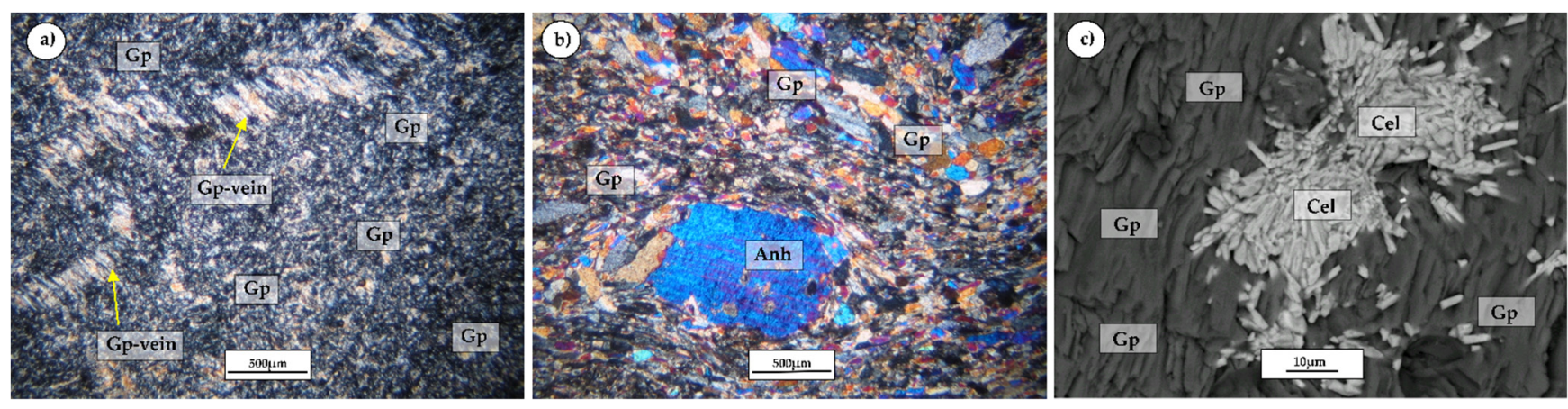

Figure 2. Crossed polars photomicrographs of: (a) Gypsum-rich sample SK-2 composed of alabastrine gypsum, with veins filled with oriented gypsum crystals. (b) Gypsum-rich sample KAS-1 composed of alabastrine to granoblastic gypsum. Oversize crystal and residues of anhydrite crystals appear, with the form of boudinage. (c) Celestite crystals of irregular and prismatic form and at radial layout within the gypsum mass (gypsum-rich sample FIL-2). (Gp: Gypsum, Anh: Anhydrite, Cel: Celestite).

Relics of anhydrite and fluidal texture are also expressed with the form of boudinage (KAS-1, Figure 2b). Celestite is formed at the expense of gypsum and anhydrite. It occurs in all regions studied, under the form of irregular to prismatic crystals that have been developed within pores-fractures (Figure 2c). Dolomite is usually observed in the gypsum-rich evaporites of Altsi (AL-1) and Etoliko (ET-2, ET-3, ET-4), often accompanying celestite (ET-4). Dolomite mostly appears at the expense of gypsum as part of the evaporitic groundmass. Calcite is detected as a major mineral component in the gypsum-rich evaporites of the Etoliko (ET-3), while magnesite is detected only in the area of Altsi (AL-2). Representative chemical compositions of selected minerals are provided in Supplementary Table S1.

\subsubsection{Anhydrite-Rich Evaporites}

Anhydrite-rich evaporites occur less frequently compared to the gypsum-rich evaporites. Their mineralogical assemblage mostly includes anhydrite (ca. 80-90\%), whereas gypsum (ca. 5-10\%) and dolomite (ca. 2-15\%) appear in the form of accessory mineral phases. Their texture is mainly heteroblastic with irregular, lomboid to vague crystal boundaries, whereas occasionally fluidal textures are also observed (AL-3). Anhydrite also appears as net of secondary veins and veinlets that crosscut relicts of gypsum-rich groundmass (e.g., Stomio region) (ST-3). Irregular and prismatic celestite crystals replaced anhydrite veins and dolomite (Stomio region). Relics of partly replaced dolomite and anhydrite are hosted within the newly-formed celestite (ST-3). Dolomite occurs at the expense of anhydrite and occasionally of gypsum and it is observed both in the regions of Stomio and Altsi.

\subsubsection{Calcite-Rich Evaporites}

Calcite-rich evaporites, identified in Katouna area, are mostly consisted of micritic limestones, with pores, veins and small cavities filled with gypsum. Their mineralogical assemblage mostly includes calcite (ca. 75-95\%), whereas dolomite (ca. 0-25\%) and gypsum (ca. $0-5 \%$ ) appear also as participating mineral phases. Quartz and sanidine are found as a trace mineral in Katouna area (KAT-4).

\subsection{Geochemistry}

The identified aforementioned groups are further confirmed by their whole rock composition. In this context, the Altsi and Stomio anhydrite-rich evaporites (samples AL-3 and ST-3) exhibit low LOI contents, whereas the LOI contents of gypsum-rich evaporites are substantially high. The total impurities of the studied evaporite are relatively low $(0.40-2.06$ w.t.\%), regardless of their classification, except for samples from Etoliko, Filiates 
and Stomio, which present considerable impurities (2.38, 7.12 and 3.06 w.t.\%) that are possibly linked with their high $\mathrm{Mg}^{2+}, \mathrm{Na}^{+}$and $\mathrm{Sr}^{2+}$ contents. The Etoliko, Altsi and Stomio evaporites (samples ET-2, AL-3, ST-1 and ST-3) exhibit the highest $\mathrm{Mg}^{2+}$ content $(1.42,0.78$, 1.95 and 1.01 w.t.\%, respectively), whereas the Filiates, Altsi and Skopos evaporites (FIL-3, AL-3, and SK-4) are more enriched in $\mathrm{Na}^{+}$compared to the other samples $(0.2,0.25$ and 0.26 w.t.\%, respectively).

The highest $\mathrm{Sr}^{2+}$ values correspond to samples the Filiates, Kastro and Katouna evaporites, (FIL-2: 6.43 w.t. $\%$, KAS-1: 1.58 w.t. $\%$, KAT-1: 1.24 w.t. $\%$ and KAT-2: 1.79 w.t. $\%$ ) and they are possibly assigned to the presence of celestite. The contents of $\mathrm{Fe}^{3+}, \mathrm{K}^{+}, \mathrm{Ti}^{4+}$, $\mathrm{P}^{5+}, \mathrm{Cl}^{-}, \mathrm{Mn}^{2+}$ and $\mathrm{Ba}^{2+}$ contents are considerably low in every evaporite (Table 1).

Table 1. Trace elements content (wt.\%) of the studied gypsum-evaporite samples.

\begin{tabular}{|c|c|c|c|c|c|c|c|c|c|c|}
\hline Sample & $\mathrm{Fe}^{3+}$ & $\mathrm{Mg}^{2+}$ & $\mathbf{K}^{+}$ & $\mathrm{Na}^{+}$ & $\mathrm{Sr}^{2+}$ & $\mathrm{Ti}^{4+}$ & $\mathbf{P}^{5+}$ & $\mathrm{Cl}^{-}$ & $\mathrm{Mn}^{2+}$ & $\mathrm{Ba}^{2+}$ \\
\hline Etoliko & 0.058 & 0.902 & 0.037 & 0.061 & 0.556 & 0.006 & 0.004 & 0.013 & 0.014 & 0.043 \\
\hline Filiates & 0.069 & 0.201 & 0.041 & 0.164 & 3.627 & 0.008 & 0.016 & 0.070 & 0.009 & 0.024 \\
\hline Altsi & 0.060 & 0.468 & 0.019 & 0.128 & 0.292 & 0.007 & 0.004 & 0.051 & 0.012 & 0.025 \\
\hline Stomio & 0.054 & 1.476 & 0.022 & 0.098 & 0.721 & 0.007 & 0.006 & 0.037 & 0.008 & 0.024 \\
\hline Skopos & 0.052 & 0.170 & 0.025 & 0.138 & 0.454 & 0.007 & 0.009 & 0.055 & 0.018 & 0.025 \\
\hline Kastro & 0.075 & 0.383 & 0.034 & 0.050 & 1.151 & 0.007 & 0.004 & 0.008 & 0.017 & 0.016 \\
\hline Katouna & 0.050 & 0.113 & 0.005 & 0.000 & 1.514 & 0.006 & 0.003 & 0.000 & 0.016 & 0.034 \\
\hline
\end{tabular}

\subsection{Whiteness}

Regarding their whiteness (Table 2), the studied evaporites can be distinguished into three groups. The first includes evaporites from Kastro and Etoliko, which exhibit the lowest average values (68.98\% and $70.96 \%$, respectively), followed by the second group of Katouna and Filiates evaporites, which show considerably higher whiteness (78.62\% and $81.73 \%$, respectively). The third high-whiteness group includes the Altsi, Stomio and Skopos evaporites whose average whiteness is within the range of $87.44-95.58 \%$.

Table 2. Average whiteness rates (\%) of the evaporite samples.

\begin{tabular}{cccccccc}
\hline Locality & Skopos & Kastro & Altsi & Stomio & Etoliko & Katouna & Filiates \\
\hline $\begin{array}{c}\text { Whiteness } \\
\%\end{array}$ & 95.58 & 68.98 & 87.44 & 92.47 & 70.96 & 78.62 & 81.73 \\
\hline
\end{tabular}

\subsection{Current Perspectives of the Deposits}

The indicative reserves of gypsum in Greece are estimated at 350 million tons with a worth of 2.1 billion $€$. The high proximity of these deposits with the seaside provides the advantage for implementation of cost-effective exploitation scenarios, characterized by lower logistic costs. The gypsum deposit in Skopos, (Zakynthos Island), is currently exploited by the company BIOGYPS KARBELIS S.A. The company trades the material mainly under the form of gypsum of artistry. The Skopos deposit is considered to be the most valuable deposit in terms of quality. The Etoliko deposit is exploited by two companies BIOGYPS KARBELIS S.A. and Saint Gobain SA (ex BPB). The extracted material of BIOGYPS KARBELIS S.A., after processing, is traded with the form of gypsum for agricultural and cement/construction industry. Saint Gobain S.A., apart from producing gypsum products such as wallboards, is also utilizing the recovered waste gypsum material coming from the production processes, adopting a circular economy framework. The Katouna deposit is exploited by the companies KNAUF and BIOGYPS KARBELIS S.A. KNAUF trades the product with the form gypsum-glue, wallboards, gypsum of artistry and gypsum of buildings. The Altsi deposit is exploited by three companies: LAVA Mining and Quarry, subsidiary of the Heracles group, INTERBETON STRUCTURAL MATERIALS S.A., subsidiary company of the cement TITAN group and Zervakis S.A. LAVA's quarry 
production capacity amounts in $300.000 \mathrm{tn} / \mathrm{yr}$, while TITAN group covers its total needs for cement in Greece from this mine. Currently, the unexploited deposits include the Kastro-Kyllini gypsum quarry (operating until 1980s), the Filiates-Thesprotia gypsum deposits (never exploited) and the old gypsum quarries in Stomio Crete (exploited until 2000). The expansion of the Kyllini settlement, renders the relative deposit prohibitive for re-operating.

\section{Discussion and Conclusions}

Results of this study show that the evaporite samples are characterized by low variability on their trace element composition. Accordingly, their whiteness variation is influenced from the degree of recrystallization, structural defects (micro cracks, veins) or other optical (physical) properties rather than their chemical content. The average Sr contents of the Greek evaporites presented in the current study $\left(\mathrm{Sr}_{\mathrm{avg}}=11,393 \mathrm{ppm}\right)$ are substantially higher compared to those of Spain, Poland, Austria, Persian Gulf and Israel evaporites, which display considerably lower Sr values ( $\leq 5000$ ppm; [2]). In this context the Greek evaporites also exhibit higher Sr contents compared to those of the Maroni (Cyprus) and Arabian Gulf (Qatar) celestite-bearing evaporitic deposits, which present Sr contents $\leq 3000$ ppm [11]. Despite their general Sr-rich nature, the Greek evaporites do not present compositional homogeneity with $\mathrm{Sr}$ contents ranging between 1099 and 64,265 ppm. Hence, the Filiates, Katouna and Kastro deposits, which are substantially enriched in $\mathrm{Sr}(15,812-64,265$ $\mathrm{ppm}$ ), should be further investigated as they can be considered prosperous for future $\mathrm{Sr}$ exploitation.

Petrographic and mineralogical study of the studied evaporitic rocks indicates that gypsum and anhydrite were consumed in favor of celestite precipitation. This is a common replacement that usually takes place in evaporitic rocks [12,13]. In particular, precipitation of celestite is favored by mixing processes between hypersaline and meteoric waters, combining the $\mathrm{SO}_{4}{ }^{2-}$ ions that were derived from the dissolution of calcium-sulphate mineral phases with $\mathrm{Sr}^{2+}$; the latter is usually derived from bacterially-mediated calcitisation of anhydrites and/or marine-brines [14-16]. The dissolution mechanisms of Ca-sulphates can be plausibly attributed to subaerially exposed gypsum [17]. The formation of dolomite also indicates that the pore waters, which were involved in dolomitization presented elevated $\mathrm{Mg} / \mathrm{Ca}$ ratios [18]. The presence of irregular and prismatic celestite at the expense of dolomite also suggests that celestite was further precipitated during dolomitisation of limestones. Limestones in proximity to the precipitation site along with microbial activity, could provide Ca-rich and to a smaller extent Sr-rich groundwaters, highlighting the effect of the exposure/karstification process [2]. The aforementioned indicate that celestite can be distinguished into two types that were formed under distinct physicochemical conditions.

The location of deposits near seaside, along with their high qualitative characteristics (low impurity content and whiteness), constitutes the deposits financially efficient, for a wide range of industrial uses. Currently, the only unexploited reserves are those of Stomio (Crete Island, partially exploited in the past), Kastro (Kyllini region) and Filiates (Thesprotia region). Stomio deposit, is suitable for artistry plaster, apart from being applied in the construction and agriculture industry, due to its high whiteness. However, obstacles associated with the adjacent monastery and high-touristic beach (Elafonissi) are yet to be overcome for the re-operation of the mine. The Filiates deposit is highly recommended for further investigation and exploitation, not only for its large gypsum reserves (up to 100 million tons) but also for celestite extraction. Its proximity to Igoumenitsa harbor for exports to Europe and the proximity to Albania and TITAN S.A. Albanian cement factory can create an attractive investment.

Supplementary Materials: The following are available online at https:/ /www.mdpi.com/article/10 .3390/materproc2021005003/s1, Table S1: Representative chemical composition of selected minerals.

Author Contributions: Conceptualization, I.B., S.N., M.S.; methodology, I.B., S.N., M.S.; software, I.B., S.N., M.S., C.K.; validation, I.B., M.S., N.K., P.K.; investigation, I.B., S.N., M.S.; resources, M.S.; 
data curation, I.B., S.N., M.S., C.K., P.K.; writing-original draft preparation, I.B., S.N., M.S., C.K., N.K., P.K.; writing-review and editing, I.B., S.N., M.S., C.K., N.K., P.K.; visualization, I.B., S.N., M.S.; supervision, I.B., M.S., N.K. All authors have read and agreed to the published version of the manuscript.

Funding: This research received no external funding.

Acknowledgments: Authors would like to express their sincerest appreciation to Pomoni-Papaioannou Fotini, for her notes at the optical microscopy analysis; Mitsis Ioannis, for his laboratory support; Michailidis Evangelos (laboratory testing staff), for his assistance during the SEM analysis, at the Department of Mineralogy and Petrology; Fragoulis Dimtrios, chemical engineer of TITAN S.A., for his laboratory support at TITAN S.A. labs; Karvelis Ioannis, owner of Biogyps Karvelis S.A., for its collaboration for the collection of our samples; and Aimilos Georgiou, from TITAN SA, for providing us with the two Filiates-Thesprotia samples. In addition, we would like to thank Panagiota-Elpida Tsekoura (Geologist) for her support.

Conflicts of Interest: The authors declare no conflict of interest.

\section{References}

1. Garside, M. Major Countries in Gypsum Mine Production 2010-2020. Available online: https://www.statista.com/statistics/26 4936/global-gypsum-production-by-major-countries / (accessed on 9 June 2021).

2. Warren, J.K. Evaporites: A Geological Compendium; Springer: Berlin/Heidelberg, Germany, 2016; pp. 735-743.

3. Singerling, S.A. Strontium [advance release]. In Metals and Minerals: U.S. Geological Survey Minerals Yearbook; USGS: Reston, VA, USA, 2017.

4. European Commission. Study on the EU's List of Critical Raw Materials_Final Report; European Commission: Belgium, Brussels, 2020.

5. Kilias, A.; Vamvaka, A.; Fassoulas, C.; Falalakis, G.; Avgerinas, S.; Sfeikos, A.; Pipera, K.; Katrivanos, E.; Thomaidou, E. A geological cross-section through northern Greece from Pindos to Rhodope Mountain Ranges: A field guide across the External and Internal Hellenides. J. Virtual Explor. 2016, 50, 1-107.

6. Karakitsios, V.; Roveri, M.; Lugli, S.; Manzi, V.; Gennari, R.; Antonarakou, A.; Triantaphyllou, M.; Agiadi, K.; Kontakiotis, G.; Kafousia, N.; et al. A record of the Messinian salinity crisis in the eastern Ionian tectonically active domain (Greece, eastern Mediterranean). Basin Res. 2016, 29, 203-233. [CrossRef]

7. Karakitsios, V. The influence of preexisting structure and halokinesis on organic matter preservation and thrust system evo-lution in the Ionian Basin, Northwest Greece. AAPG Bull. 1995, 79, 960-980.

8. Rigakis, N. Contribution to Stratigraphic Research on Wells and Outcrops of the Alpine Formations in Western Greece, in Rela-tion to the Petroleum Generation Efficiency of Their Organic Matter. Ph.D. Thesis, Athens University, Athens, Greece, 1999.

9. Rigakis, N.; Karakitsios, V.; Marnelis, F.; Sotiropoulos, S. Geological solutions concluded by petroleum geochemical data in Western Greece. Bull. Geol. Soc. Greece 2013, 47, 2131-2143. [CrossRef]

10. Stamatakis, M. Boron Distribution in Hot Springs, Volcanic Emanations, Marine Eaporites and Volcanic and Sedimentary Rocks of Cenozoic Age in Greece. Ph.D. Thesis, University Athens, Athens, Greece, 1986.

11. Dill, H.G.; Henjes-Kunst, F.; Berner, Z.; Stüben, D. Miocene diagenetic and epigenetic strontium mineralization in calcareous series from Cyprus and the Arabian Gulf: Metallogenic perspective on sub-and suprasalt redox-controlled base metal depos-its. J. Asian Earth Sci. 2009, 34, 557-576. [CrossRef]

12. Kushnir, J. The partitioning of seawater cations during the transformation of gypsum to anhydrite. Geochim. Cosmochim. Acta 1982, 46, 433-446. [CrossRef]

13. Orti, F.; Helvaci, C.; Rosell, L.; Gündoğan, İ. Sulphate-borate relations in an evaporitic lacustrine environment: The Sul-tancayir gypsum (Miocene, western Anatolia). Sedimentology 1998, 45, 697-710. [CrossRef]

14. Frazier, W. Celestite in the Mississippian Pennington Formation, Central Tennessee. Southeast. Geol. 1975, 16, 241-248.

15. Baker, D.M.; Lillie, R.J.; Yeats, R.S.; Johnson, G.D.; Yousuf, M.; Zamin, A.S.H. Development of the Himalayan frontal thrust zone: Salt Range, Pakistan. Geology 1988, 16, 3-7. [CrossRef]

16. Kendall, A.C. Late diagenetic calcitization of anhydrite from the Mississippian of Saskatchewan, western Canada. Sedimentology 2001, 48, 29-55. [CrossRef]

17. Taberner, C.; Marshall, J.D.; Hendry, J.P.; Pierre, C.; Thirlwall, M.F. Celestite formation, bacterial sulphate reduction and carbonate cementation of Eocene reefs and basinal sediments (Igualada, NE Spain). Sedimentology 2002, 49, 171-190. [CrossRef]

18. Wright, D.T. The role of sulphate-reducing bacteria and cyanobacteria in dolomite formation in distal ephemeral lakes of the Coorong region, South Australia. Sediment. Geol. 1999, 126, 147-157. [CrossRef] 